\title{
Bench site survey ${ }^{1}$
}

K.M. Gillis, J.E. Snow, A. Klaus, G. Guerin, N. Abe, N. Akizawa, G. Ceuleneer, M.J. Cheadle, Á. Adrião, K. Faak, T.J. Falloon, S.A. Friedman, M.M. Godard, Y. Harigane, A.J. Horst, T. Hoshide, B. Ildefonse, M.M. Jean, B.E. John, J.H. Koepke, S. Machi, J. Maeda, N.E. Marks, A.M. McCaig, R. Meyer, A. Morris, T. Nozaka, M. Python, A. Saha, and R.P. Wintsch²

\section{Chapter contents}

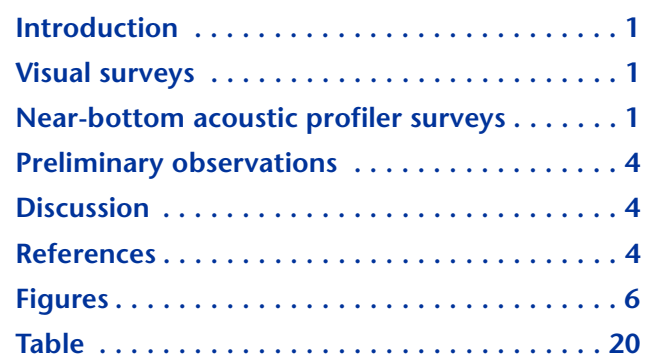

${ }^{1}$ Gillis, K.M., Snow, J.E., Klaus, A., Guerin, G., Abe, N., Akizawa, N., Ceuleneer, G., Cheadle, M.J., Adrião, Á., Faak, K., Falloon, T.J., Friedman, S.A., Godard, M.M., Harigane, Y., Horst, A.J., Hoshide, T., Ildefonse, B., Jean, M.M., John, B.E., Koepke, J.H., Machi, S., Maeda, J., Marks, N.E., McCaig, A.M., Meyer, R., Morris, A., Nozaka, T., Python, M., Saha, A., and Wintsch, R.P., 2014. Bench site survey. In Gillis, K.M., Snow, J.E., Klaus, A., and the Expedition 345 Scientists, Proc. IODP, 345: College Station, TX (Integrated Ocean Drilling Program). doi:10.2204/iodp.proc.345.103.2014

'Expedition 345 Scientists' addresses.

\section{Introduction}

A series of near-bottom surveys were conducted during Integrated Ocean Drilling Program (IODP) Expedition 345 to characterize the seafloor and shallow subsurface of the Site U1415 area (Table T1). The purpose of these surveys was to observe and characterize the nature and local slope of the seafloor and the thickness of the subsurface material covering more competent basement, with the ultimate goal of siting drill holes. The surveys were either exploratory, to characterize the area surrounding the proposed drill sites (HD-01B-HD-03B) and to assess the viability of additional areas, or targeted, to characterize a specific hole location. All of the surveys involved visual observations; five of these surveys also collected acoustic subbottom profiling data using a $3.5 \mathrm{kHz}$ near-bottom pinger. Plots of all data are available in BNCHSITE in "Supplementary material." Raw and processed data are available in digital form from the IODP Data Librarian.

\section{Visual surveys}

Fourteen visual surveys of the seafloor were conducted during Expedition 345 (Table T1). Archived video is available from the IODP Data Librarian. For all surveys, the vibration isolated television (VIT)-mounted camera (Fig. F1) was placed 2-5 $\mathrm{m}$ above the bottom of the drill string, with the drill string $2-5 \mathrm{~m}$ above the seafloor. Observations of the nature of the seafloor (e.g., monotonous sediment or surficial rubble) and periodic estimations of the regional slope using the VIT-mounted Mesotech sonar were recorded. For exploratory surveys, a predetermined track was followed to cover a region of interest. For targeted surveys, the drill string and VIT moved from an abandoned hole to a new location. When a specific site was deemed acceptable for drilling, a box survey expanding 5-10 $\mathrm{m}$ from the origin was conducted to ensure that the seafloor was free of surface rubble. Typically, the drill string made two or more seafloor tags during the box survey to confirm depth and assess the local slope.

\section{Near-bottom acoustic profiler surveys}

A crucial operational variable to the success of Expedition 345 was the thickness of the surficial zone (sediment and rubble) covering the plutonic basement. The options for reentry were a standard 
reentry cone on a short conductor casing, a nested free-fall funnel (FFF), or a variety of untested ideas for establishing a cased hole (see "Drilling strategy" in the "Expedition 345 summary" chapter [Gillis et al., 2014a]). The chances of successfully establishing any of these reentry structures and achieving deep penetration at Hess Deep were initially thought to increase with the thickness of the cover. The potential to remotely estimate sediment thickness without having to probe each point with the drill bit was useful for locating drill sites with the thickest apparent cover.

The rugged terrain and deep water effectively negated the ability of most kinds of surface reflection profiling, primarily because of the multiple reflections from various parts of the slope that obscured the signal from the targeted formation. The problem was compounded by the very small size of the flat bench that was our target. Because of the thin sediment cover (estimated before the expedition to be $<15 \mathrm{~m}$ thick), the seafloor return from a surface seismic source would have an arrival thicker than the sediment to be imaged. Sediment thicknesses also could not be assumed to be constant over large areas or to be similar to thicknesses anywhere else in the region. A single result from a highly processed narrow-angle subbottom profiling system gave an estimate of $\sim 15 \mathrm{~m}$ sediment thickness in a single locality on the bench.

For these reasons, we used a near-bottom reflection system to image the shallow subseafloor along the bench. Compared to the $\sim 500 \mathrm{~m}$ diameter of typical insonation regions for hull-mounted systems, locating the $3.5 \mathrm{kHz}$ transducer near the bottom of the drill string reduced the size of the imaged region of the seafloor to $\sim 10 \mathrm{~m}$ in diameter (Bolmer et al., 2006; Stephen, Kasahara, Acton, et al., 2003), similar to the resolution of the near-bottom swath bathymetry that formed the main basis for the local geologic interpretation on this expedition (Ferrini et al., 2013).

\section{Instrumentation and operations}

An ORE Accusonics pinger (model 263Z) consisting of a $3.5 \mathrm{kHz}$ transducer connected with a 5 inch diameter, 33 inch long pressure housing containing a battery pack, a storage capacitor, and electronics was mounted on the VIT frame (Fig. F1). This free-running pinger produces a $2 \mathrm{~ms}$ pulse every second, skipping every ninth ping to distinguish itself from other sonic sources. The signal was recorded using the ship's $3.5 \mathrm{kHz}$ transceivers housed in the sonar dome located $45 \mathrm{~m}$ forward of the moonpool.

For each survey, the pinger was started briefly before the VIT frame was sent down the drill string and kept transmitting until it came back to the surface or stopped operating because of battery or other failures. Several of the surveys were interrupted for what was originally thought to be a failure of the batteries. After several failures, the pinger was thoroughly examined, and repairs were made to its NiCd batteries, control electronics, transducer, and insulation before its final deployments, during which it performed flawlessly.

\section{Data acquisition and processing}

Acoustic returns were acquired by the ship's $3.5 \mathrm{kHz}$ sonar dome and processed using the SyQwest Bathy 2010 electronics and software that runs the ship's transducer. The Bathy 2010 control software allowed us to configure the downhole sonar package for preacquisition analog processing (timing, filtering, and initial amplification) and was able to display the signal. The passive mode of the software did not function correctly, so it was set manually to maximum depth and minimum output power.

The analog output was split into an unmodified signal path and a second signal path that received further filtering and amplification. The unmodified signal was digitized using a National Instruments highresolution digitizer board (NI PCI-5124) controlled by a shipboard-developed LabView application (BathyMaster) that acquires, displays, and records voltages along with ship and beacon position data.

The second signal was amplified with an ITHACO 455 amplifier and split again, with one line going to an EPC model 9802 graphic recorder and the second to a PC running Triton's SB-logger software. The EPC 9802, which was used in the past for similar experiments, received printer control and time/position annotation from another LabView application and provided a direct display of the data, but the thermal paper provided only very low contrast images. GPS data were provided by the WinFrog navigation system, and beacon offset data were provided by the Nautronics RS925 acoustic tracking software (part of the ship's automatic stationkeeping system).

The BathyMaster acquisition module allowed realtime monitoring of the data, which included the direct wave, seafloor, and subseafloor returns, once the pinger was in range of the bottom. Data visualization provided the ability to estimate the pinger height off bottom, the sediment thickness of individual traces, and a stacked view of traces lined up on the incoming direct wave. The latter, using an assumed mean sound velocity, was particularly useful for seeing subseafloor returns that tended to appear only when lined up with a number of traces. For two of the later surveys, the Triton SB-Logger seismic data acquisition and playback application provided 
an enhanced display of the subbottom reflectivity with advanced filters and display possibilities but no thickness estimation.

Each system produced its own data format of the same data. The primary format used for shipboard postprocessing was the raw data produced by the Labview acquisition routine, in which the direct arrival was already synchronized across all traces. These raw data were converted to standard seismic formats before being displayed or processed to refine our real-time interpretation.

\section{Shipboard postprocessing}

The conversion of the data and several steps of processing were performed with a combination of Cshell scripts and the Seismic Unix package (release 43 R1; www.cwp.mines.edu/cwpcodes/):

1. Data were filtered with a $3.4-3.6 \mathrm{kHz}$ bandpass filter to reduce some of the noise.

2. Gains were equalized across all traces of each survey to correct amplitude variations during the acquisition.

3. The instantaneous amplitude of each trace was calculated to enhance the intervals of high reflectivity expected in the sediments.

4. Using the amplitude data, the seafloor reflection was automatically identified along each track, and all traces were aligned to the seafloor to correct for the variations in the depth of the pinger and clearly show the vertical extent of the highreflectivity intervals.

To convert traveltime to depth and get an estimate of the actual depth and thickness of the observed features of the acoustic profile, it was necessary to assume a velocity profile to provide a conversion between depth and transit time. We used the velocity data obtained from discrete core samples during Ocean Drilling Program (ODP) Leg 147 and Expedition 345 (see "Physical properties" in the "Methods" chapter [Gillis et al., 2014c]) to define two velocity models constraining our time-depth conversion (Fig. F2). Data from Leg 147 Sites 894 (gabbro) and 895 (serpentinized peridotite and gabbro) suggest a compressional velocity of $\sim 4 \mathrm{~km} / \mathrm{s}$ below the surficial zone and probably represent a lower bound on effective crustal velocity. All data recorded at Site U1415 suggest values closer to $6 \mathrm{~km} / \mathrm{s}$. These two depth scales are shown on all of the instantaneous amplitude figures.

\section{Data}

Although the pinger was deployed on multiple occasions with the VIT camera, the data presented here were recorded during five surveys that were carried out to help identify favorable drilling locations (Table T1; Fig. F3). The ship was moved in dynamic positioning mode during all surveys, keeping the VIT camera in visual contact with the seafloor. Data were recorded continuously while the ship was in motion and also when it was on station, either while adding or removing pipe, during detailed visual inspections of the seafloor in some areas, or during jet-in tests. The data shown in this chapter are only those recorded while the ship was moving along transects that were designed to characterize the structure under targeted drilling areas. The entire tracks, including the traces recorded while stationary, are available in BNCHSITE in "Supplementary material."

\section{December 2012 survey}

This initial survey was designed to provide a complete overview of the entire bench that was the main target area for Expedition 345. This survey was conducted before any hole was drilled to assess local variations in the surficial zone thickness, as this would influence the choice of drilling approaches used (see "Drilling strategy" in the "Expedition 345 summary" chapter [Gillis et al., 2014a]). Initially designed along three east-west lines along the bench, this survey was interrupted during the second line when the pinger stopped transmitting. The map and data of this survey are shown in Figures F4 and F5.

\section{December 2012 survey}

This survey was conducted over the eastern side of the bench after failing to achieve significant penetration during the jet-in tests in Holes U1415B-U1415D and pilot Hole U1415E in the central section of the bench (Fig. F3). After encountering consistent drilling difficulties in these locations, the goal of this survey was to complete the original survey plan for the bench and identify areas with thin cover. The map and data for this survey are shown in Figures F6 and F7, respectively. As this survey followed a winding path and several holes were attempted in its vicinity, the perspective views in Figure F8 provide a more encompassing view of this key area.

\section{January 2013 survey}

During a break in drilling operations in order to cement Hole U1415J, this survey targeted an upslope promontory or shoulder $\sim 400 \mathrm{~m}$ northwest and 160 $\mathrm{m}$ shallower than the bench in Hole U1415J. The morphology of the upslope shoulder suggested that drilling would be feasible and limited rubble should be encountered. The main east-west transect and the two north-south branches are shown in Figures F9 and F10. 


\section{January 2013 survey}

Without any significant drilling progress on the upslope shoulder, this short survey was conducted at the eastern end of the bench east of Hole U1415J to try to find drilling conditions similar to Hole U1415J, in which the deepest penetration of the expedition had been achieved. The map and data of this survey are shown in Figures F11 and F12.

\section{February 2013 survey}

After the attempts to record downhole logs in Hole U1415P were aborted and before it was time to prepare for the transit to Panama, the pinger was deployed for one last survey on 5 February to try to complete the geophysical characterization of this site where the highest recovery of the expedition had been achieved. The data of this survey are shown in Figure F13.

\section{Preliminary observations}

One of the main observations common to all of the surveys is that the layer with high reflectivity (or high amplitude) immediately below the seafloor, which is presumably made of unconsolidated pelagic sediment, lithic debris, and/or boulders, appears to vary between 4 and $20 \mathrm{~m}$ thick. The lack of coherent reflectors in these high-reflectivity intervals suggest, along with the drilling results, that they are made of highly heterogeneous materials and unconsolidated rubble.

Another possibly significant observation is the occurrence of various deeper reflectors in the images, some as deep as $200 \mathrm{~m}$, that suggest that the pinger was able to image the deep structure underlying the surveyed areas. Most of these reflectors are observed on transects and segments recorded along a northsouth direction. Whereas some reflectors are dipping to the south (Traces 2800-3400 in Fig. F7A and Traces 4200-4400 in Fig. F12A) and seem to suggest faulting parallel to the slope, others are dipping to the north (Traces 4800-5000 and 7800-8400 in Fig. F7A), suggesting conjugate deformation. Because of the proximity of the pinger to the seafloor and the variety in the character of the reflectors, many of these reflectors are likely indications of subseafloor structure. One of the strongest southward-dipping reflectors (Traces 2800-3400 in Fig. F7A) appears to intersect Hole U1415J somewhere between 60 and 100 meters below seafloor, which might be related to the cataclasites and fractured formation conditions we observed in the bottom of the hole (see the "Hole U1415J" chapter [Gillis et al., 2014b). These conditions led to the eventual abandonment of the hole.

\section{Discussion}

A preliminary geologic interpretation can be made from these data. The original model formed on the basis of the site survey microbathymetry (Ferrini, et al., 2013) and presented in the cruise proposal was that the Hess Deep bench forms a single coherent block or slab transported by dip-slip motion along a fault subparallel to the slope of the rift valley wall. The bench itself would thus represent the top of the fault block. Several scenarios for the dip fault were part of the initial planning for the expedition. The $3.5 \mathrm{kHz}$ acoustic observations suggest that at a finer scale, the bench could include several smaller fault or slump blocks with a complicated structural relationship along and across strike. This arrangement would be typical of one or more landslide or mass wasting events, a geologic model that was considered in the course of the expedition based on a reinterpretation of the microbathymetry data and on petrologic and paleomagnetic observations (see the "Expedition 345 summary" chapter [Gillis et al., 2014a]).

\section{References}

Bolmer, S.T., Hoskins, H., and Stephen, R.A., 2006. Data report: $4-\mathrm{kHz}$ profiling with vertically separated source and receiver: a mini reflection survey around a deepwater drill hole. In Kasahara, J., Stephen, R.A., Acton, G.D., and Frey, F.A. (Eds.), Proc. ODP, Sci. Results, 200: College Station, TX (Ocean Drilling Program), 1-17.

doi:10.2973/odp.proc.sr.200.005.2006

Ferrini, V.L., Shillington, D.J., Gillis, K., MacLeod, C.J., Teagle, D.A.H., Morris, A., Cazenave, P.W., Hurst, S., Tominaga, M., and the JC21 Scientific Party, 2013. Evidence of mass failure in the Hess Deep Rift from multi-resolutional bathymetry data. Mar. Geol., 339:13-21. doi:10.1016/j.margeo.2013.03.006

Gillis, K.M., Snow, J.E., Klaus, A., Guerin, G., Abe, N., Akizawa, N., Ceuleneer, G., Cheadle, M.J., Adrião, Á., Faak, K., Falloon, T.J., Friedman, S.A., Godard, M.M., Harigane, Y., Horst, A.J., Hoshide, T., Ildefonse, B., Jean, M.M., John, B.E., Koepke, J.H., Machi, S., Maeda, J., Marks, N.E., McCaig, A.M., Meyer, R., Morris, A., Nozaka, T., Python, M., Saha, A., and Wintsch, R.P., 2014a. Expedition 345 summary. In Gillis, K.M., Snow, J.E., Klaus, A., and the Expedition 345 Scientists, Proc. IODP, 345: College Station, TX (Integrated Ocean Drilling Program). doi:10.2204/iodp.proc.345.101.2014

Gillis, K.M., Snow, J.E., Klaus, A., Guerin, G., Abe, N., Akizawa, N., Ceuleneer, G., Cheadle, M.J., Adrião, Á., Faak, K., Falloon, T.J., Friedman, S.A., Godard, M.M., Harigane, Y., Horst, A.J., Hoshide, T., Ildefonse, B., Jean, M.M., John, B.E., Koepke, J.H., Machi, S., Maeda, J., Marks, N.E., McCaig, A.M., Meyer, R., Morris, A., Nozaka, T., Python, M., Saha, A., and Wintsch, R.P., 2014b. Hole U1415J. In Gillis, K.M., Snow, J.E., Klaus, 
A., and the Expedition 345 Scientists, Proc. IODP, 345: College Station, TX (Integrated Ocean Drilling Program). doi:10.2204/iodp.proc.345.110.2014

Gillis, K.M., Snow, J.E., Klaus, A., Guerin, G., Abe, N., Akizawa, N., Ceuleneer, G., Cheadle, M.J., Adrião, Á., Faak, K., Falloon, T.J., Friedman, S.A., Godard, M.M., Harigane, Y., Horst, A.J., Hoshide, T., Ildefonse, B., Jean, M.M., John, B.E., Koepke, J.H., Machi, S., Maeda, J., Marks, N.E., McCaig, A.M., Meyer, R., Morris, A., Nozaka, T., Python, M., Saha, A., and Wintsch, R.P., 2014c. Methods. In Gillis, K.M., Snow, J.E., Klaus, A., and the Expedition 345 Scientists, Proc. IODP, 345: College Station, TX (Integrated Ocean Drilling Program). doi:10.2204/ iodp.proc.345.102.2014

Stephen, R.A., Kasahara, J., Acton, G.D., et al., 2003. Proc. ODP, Init. Repts., 200: College Station, TX (Ocean Drilling Program). doi:10.2973/odp.proc.ir.200.2003

Publication: 12 February 2014 MS 345-103 
Figure F1. Vibration isolated television (VIT) frame and the location of the ORE $3.5 \mathrm{kHz}$ Accusonics pinger, silicon intensifier target (SIT) camera, and Mesotech sonar system, Expedition 345.

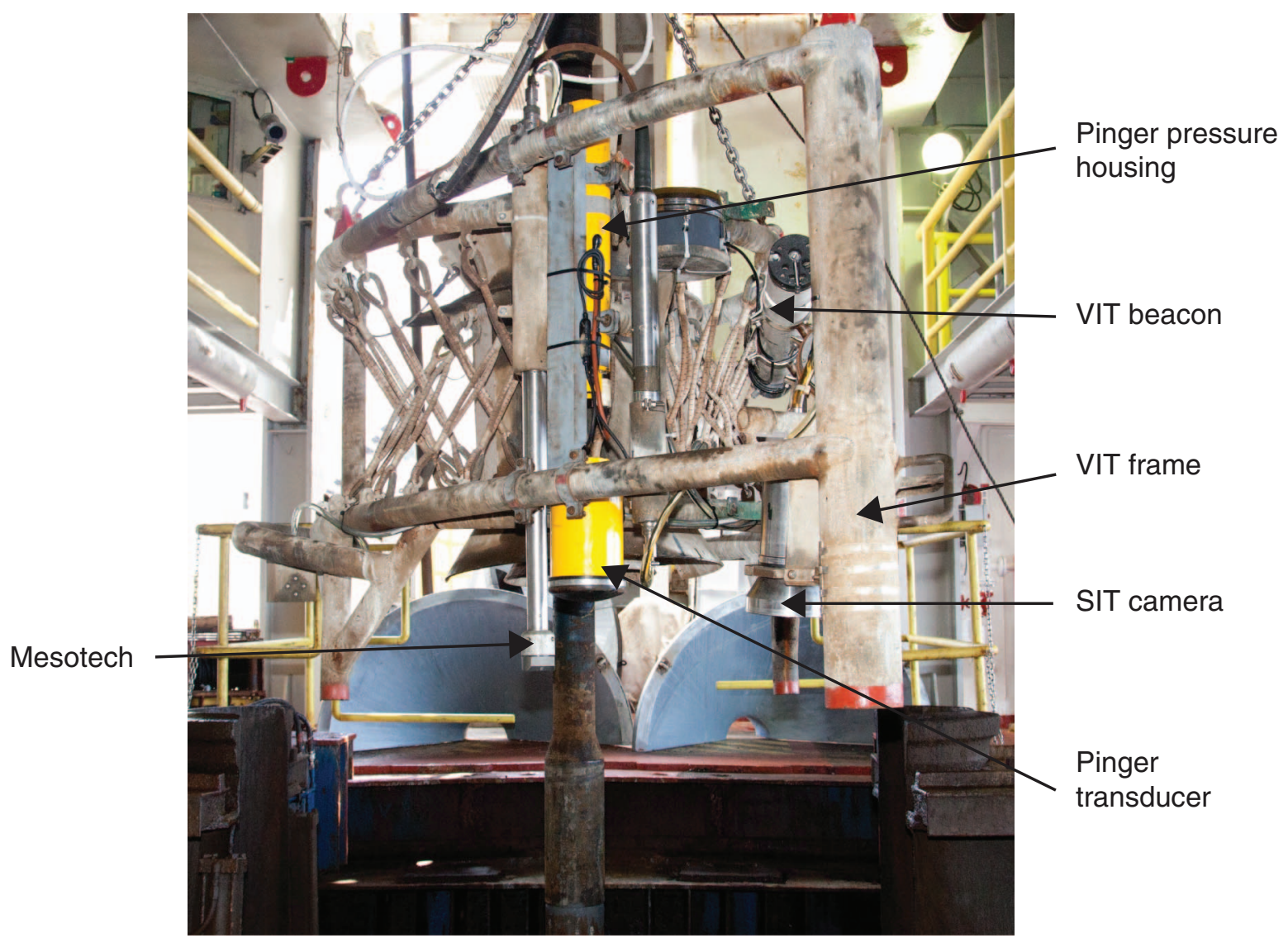


Figure F2. Velocity profiles used to convert traveltime in pinger images to depth. The two solid lines, with velocity at depth around 4 and $6 \mathrm{~km} / \mathrm{s}$, were constrained by the vertical velocity measurements made on core samples from Site U1415 and Ocean Drilling Program (ODP) Leg 147. The lower velocity curve, derived from Site 895 measurements of serpentinized peridotite, probably represents a lower bound on the potential velocities to be expected in the formation (white depth scales in Figs. F5, F7, F10, F12, F13).

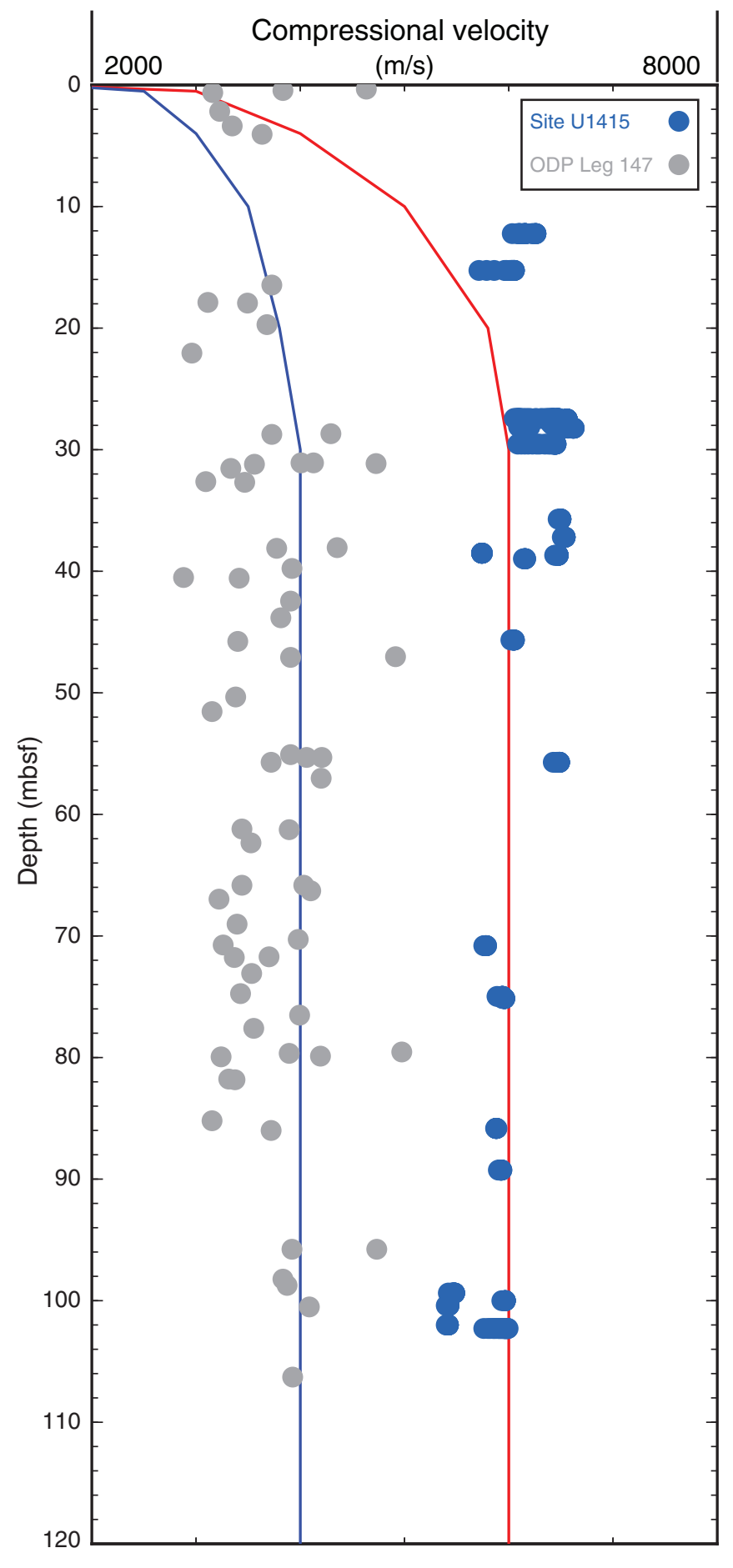


Figure F3. Subbottom profiler survey location and tracks and locations of all holes drilled at Site U1415. Surveys were recorded on 23 (blue) and 26 (red) December 2012, on 9 (yellow) and 25 (cyan) January 2013, and on 5 (green) February 2013. Microbathymetry data from Ferrini et al. (2013). Contour interval = $10 \mathrm{~m}$.

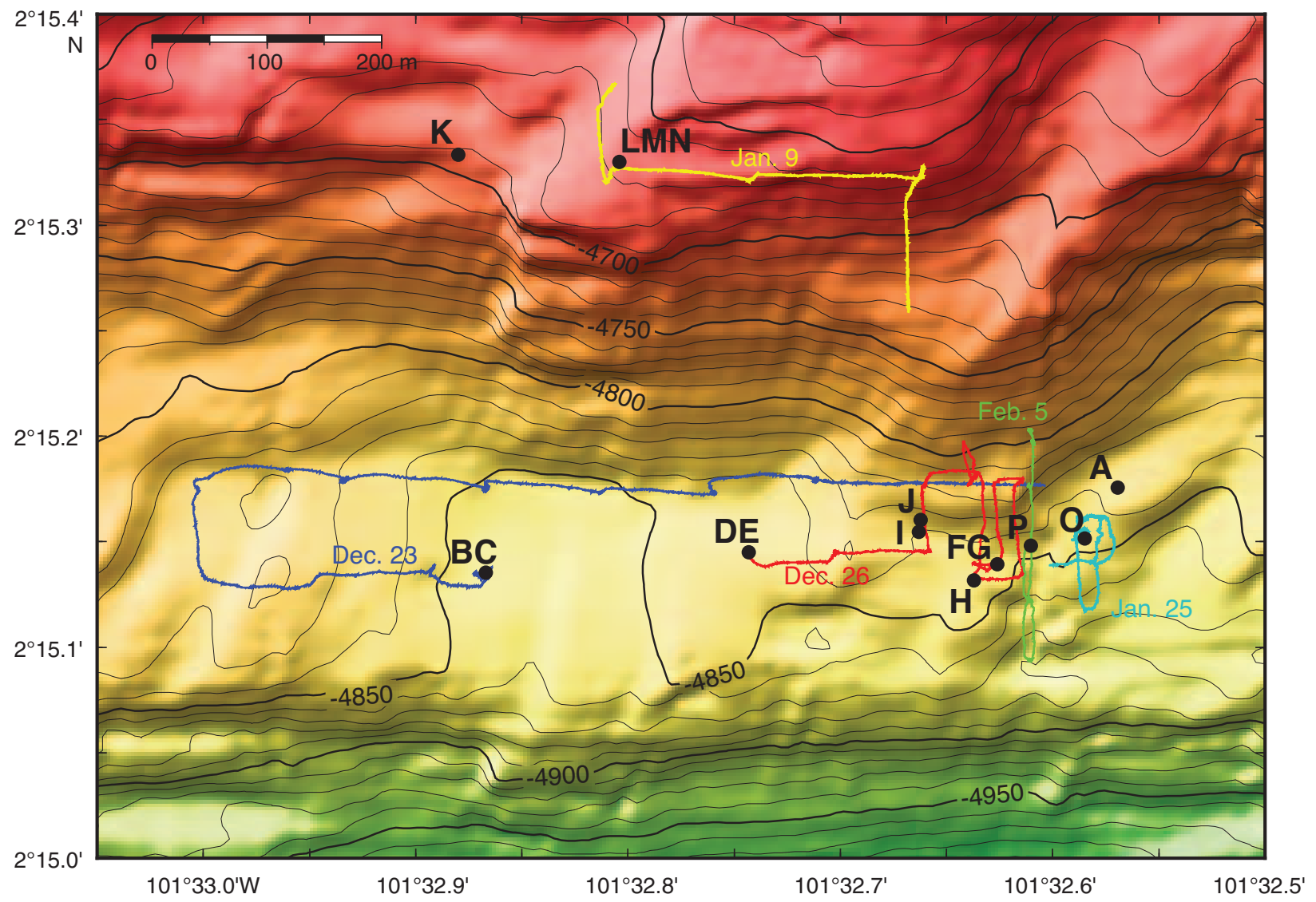


Figure F4. Pinger survey recorded on 23 December 2012, Expedition 345. Numbers on the tracks are the sequential numbers of the traces recorded at an approximate rate of 1 trace per second. Letters refer to the holes drilled. Data recorded along the blue and red sections are shown in Figure F5. Microbathymetry from Ferrini et al. (2013). Contour interval $=5 \mathrm{~m}$.

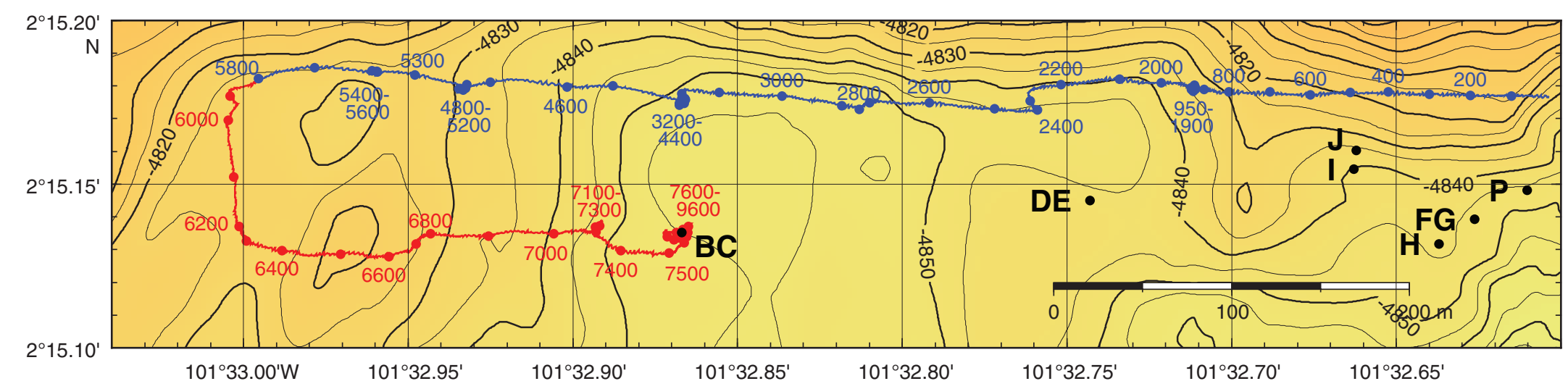


Figure F5. Subbottom profiler data recorded during the 23 December 2012 survey, Expedition 345. Traces recorded while the ship and the pinger were stationary have been removed. Upper panels show the data after filtering and equalization. The perception of the seafloor depth is biased by the variations in depth of the vibration-isolated television frame. The center panels show the water depth along the survey track, as extracted from the microbathymetry data recorded by the remotely operated vehicle Isis (Ferrini et al., 2013). The lower panels show the instantaneous amplitude of the traces after being shifted to the seafloor. Depth below seafloor is estimated from the velocity profiles shown in Figure F2. Microbathymetry data from Ferrini et al. (2013). A. Northern segment of the survey (blue in Fig. F4). BC = approximate location of Holes U1415B and U1415C. B. Western and southern segments (red in Fig. F4). Numbers are the sequential trace numbers that can be used to tie the images to their location on the map in Figure F4. (Figure shown on next page.) 
Figure F5 (continued). (Caption shown on previous page.)
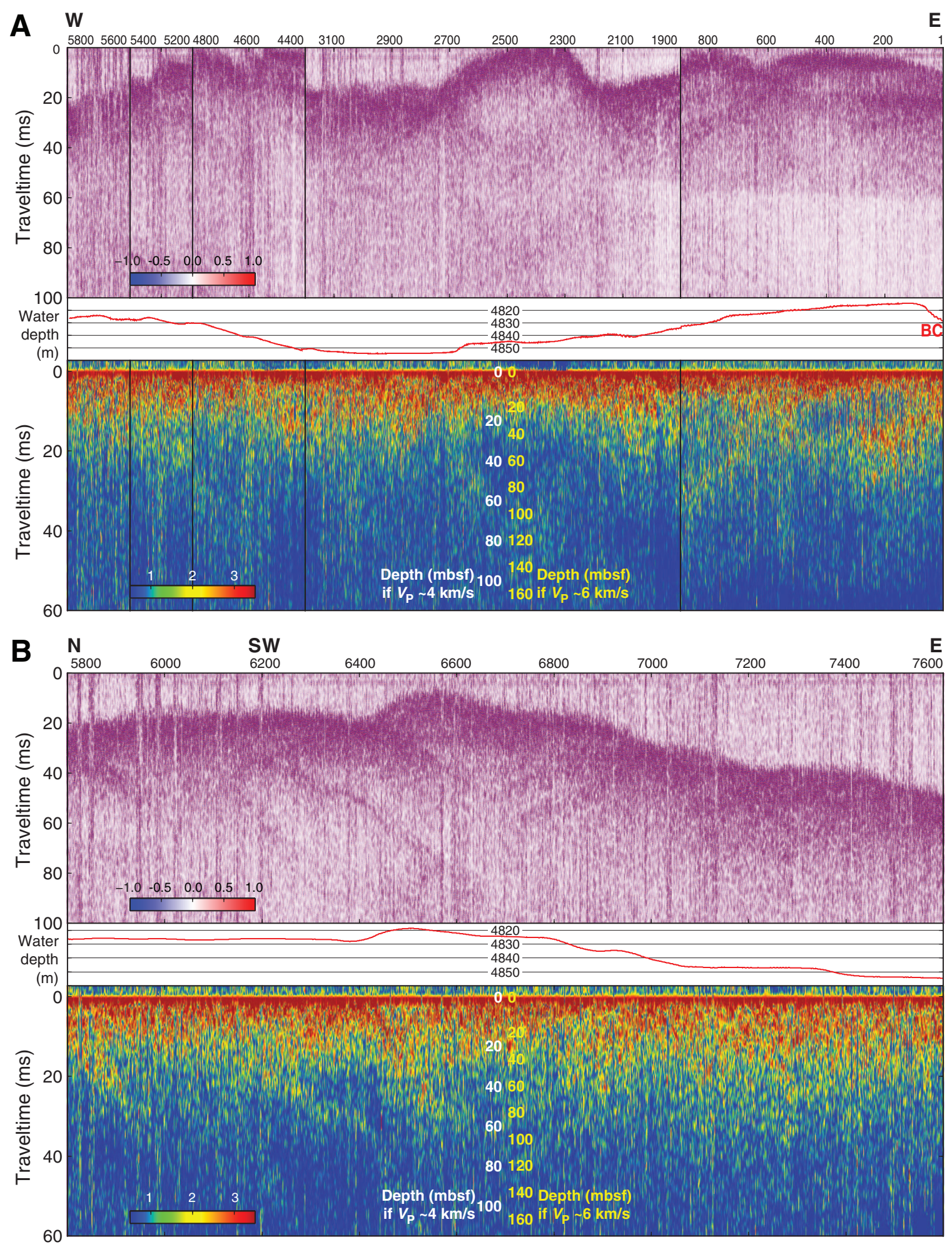
Figure F6. Pinger survey recorded on 26 December 2012, Expedition 345. The numbers on the tracks are the sequential numbers of the traces. The data recorded along the blue and red sections are shown in Figure F7. Microbathymetry from Ferrini et al. (2013). Contour interval $=5 \mathrm{~m}$.

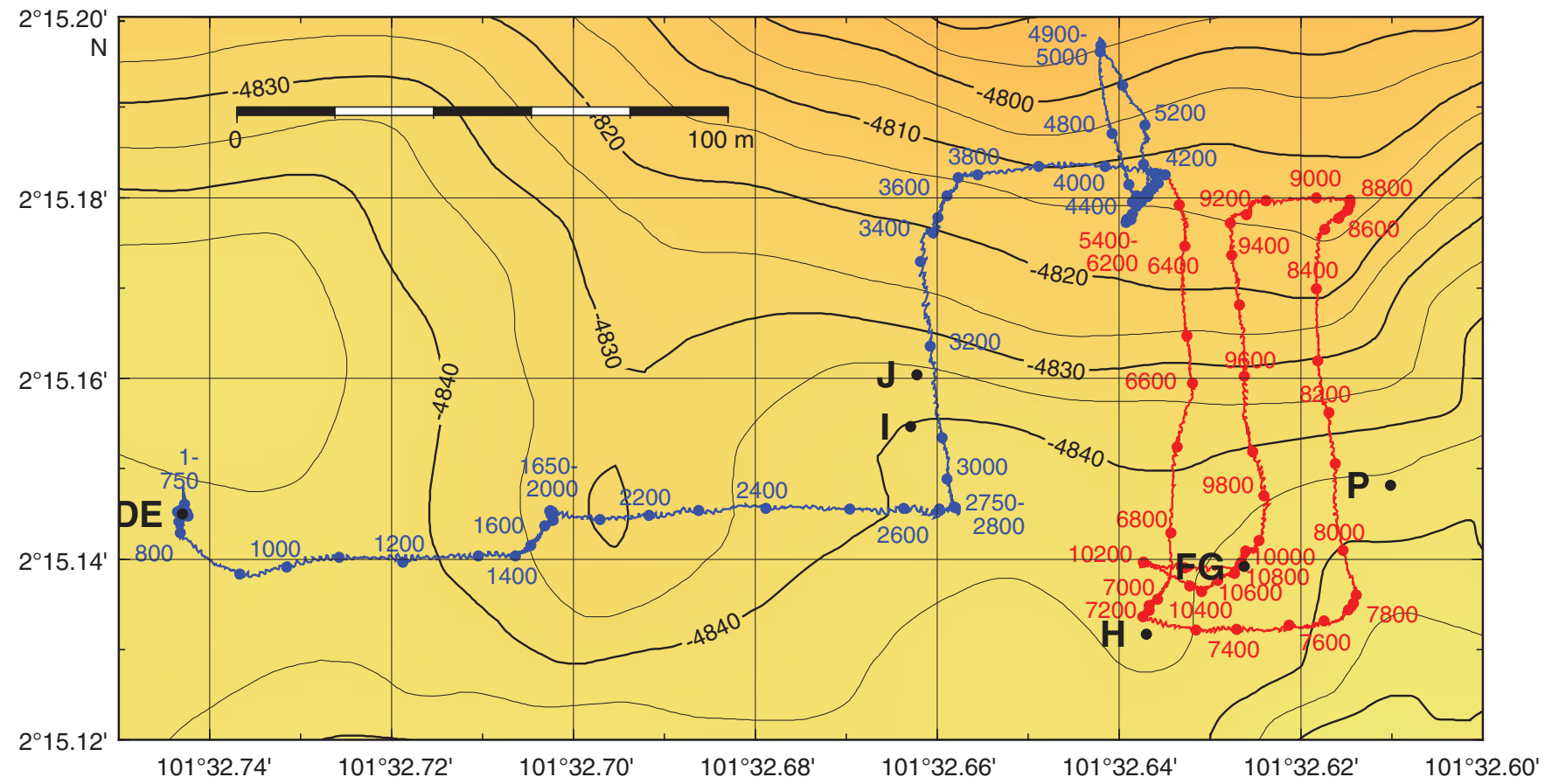


Figure F7. Subbottom profiler data recorded during the 26 December 2012 survey, Expedition 345. A. Western section of the survey (blue in Fig. F6). B. Eastern section (red in Fig. F6). See Figure F5 for details. The approximate locations of Holes U1415D-U1415P, all near this survey track, are shown on the bathymetry profile.
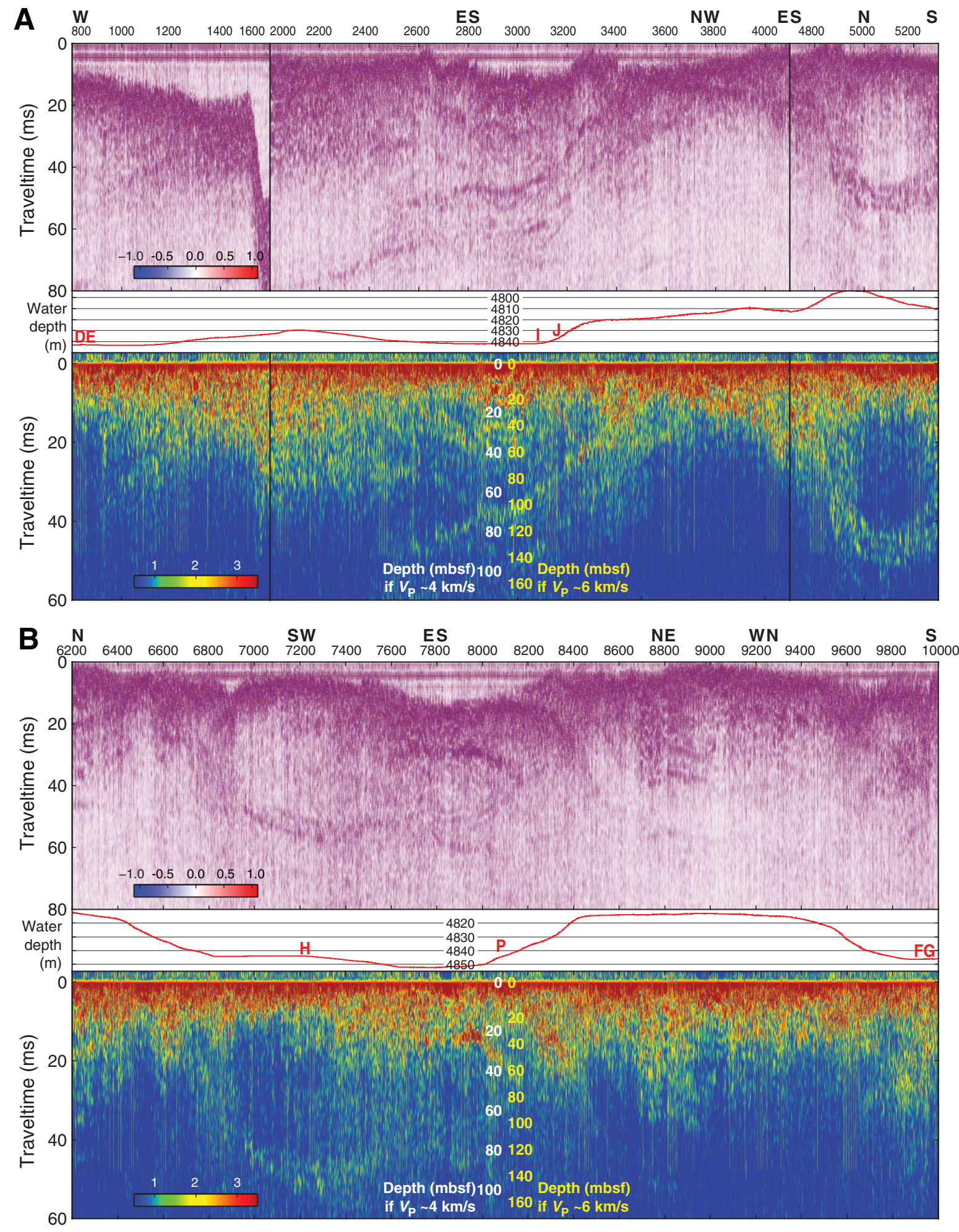
Figure F8. Perspective views from (A) northwest and (B) southeast of the amplitude of data recorded during the 26 December 2012 survey, Expedition 345. Data are the same as in Figure F7.

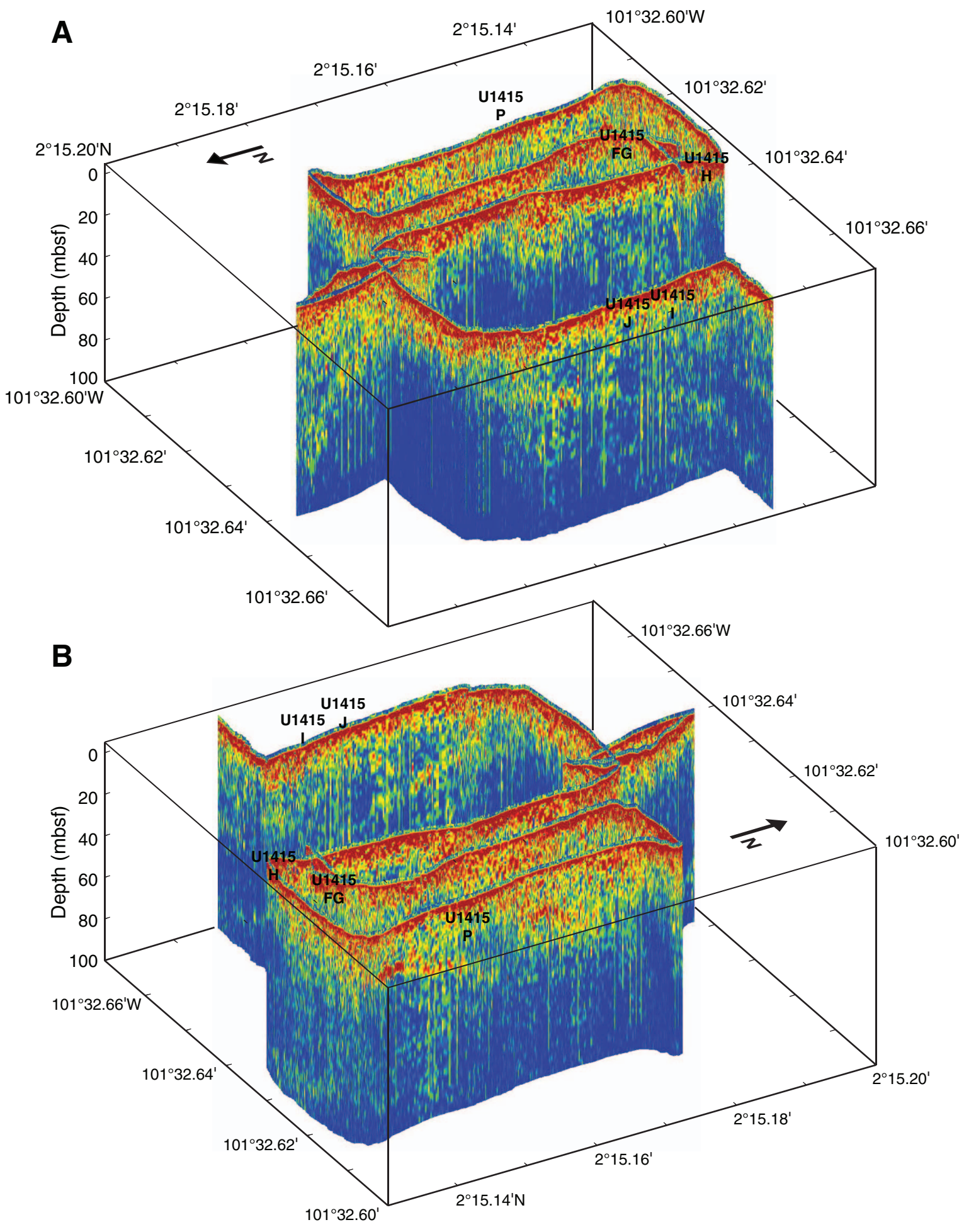


Figure F9. Pinger survey recorded on 9 January 2013, Expedition 345. The numbers are the sequential numbers of the traces. The data recorded along the blue and yellow sections are shown in Figure F10. Microbathymetry from Ferrini et al. (2013). Contour interval $=5 \mathrm{~m}$.

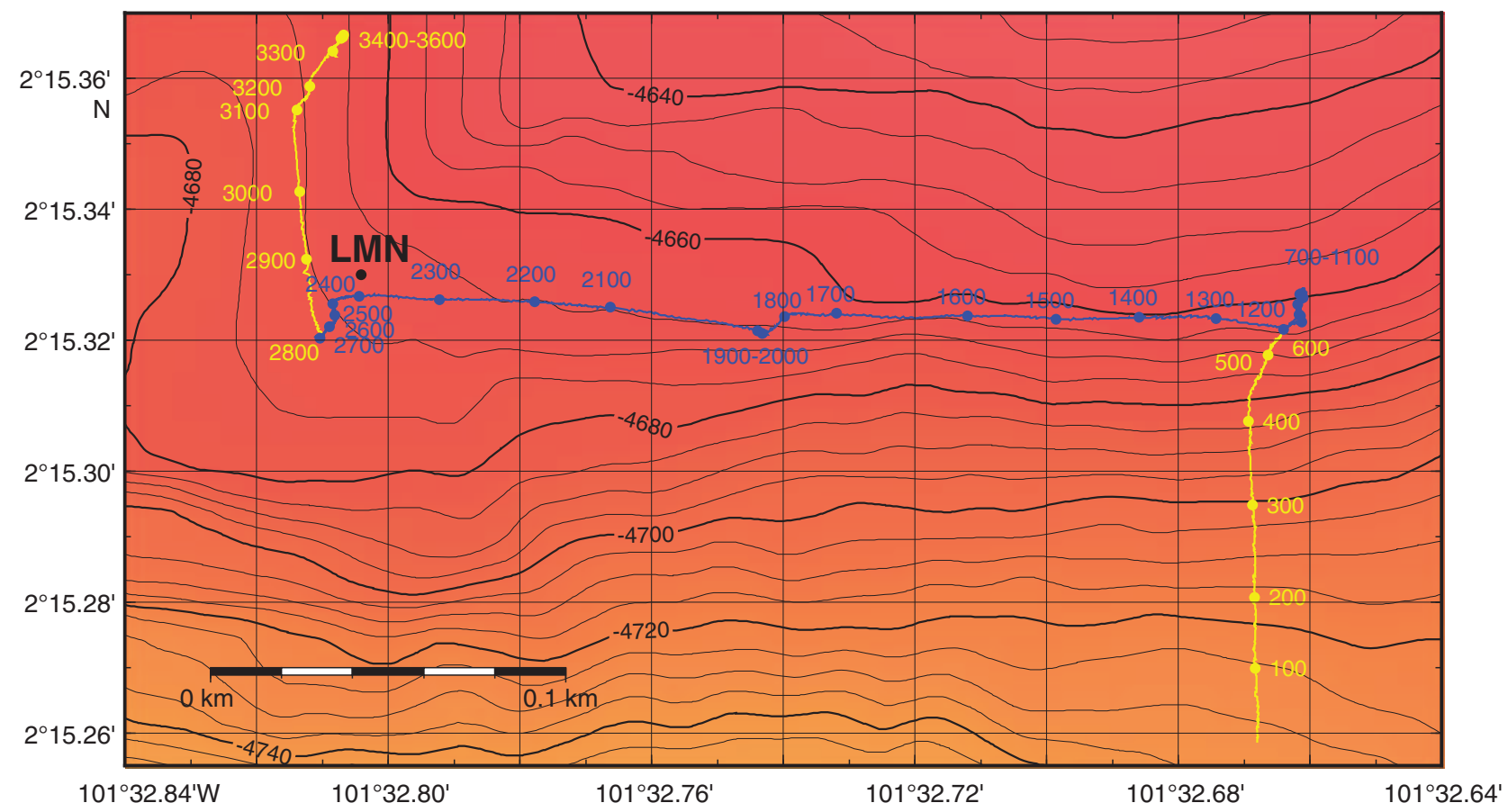


Figure F10. Subbottom profiler data recorded during the 9 January 2013 survey, Expedition 345. A. East-west transect (blue in Fig. F9). B. North-south branches recorded at the beginning and the end of the survey (yellow in Fig. F9). See Figure F5 for details. The approximate locations of Holes U1415L-U1415N are shown on the bathymetry profile.
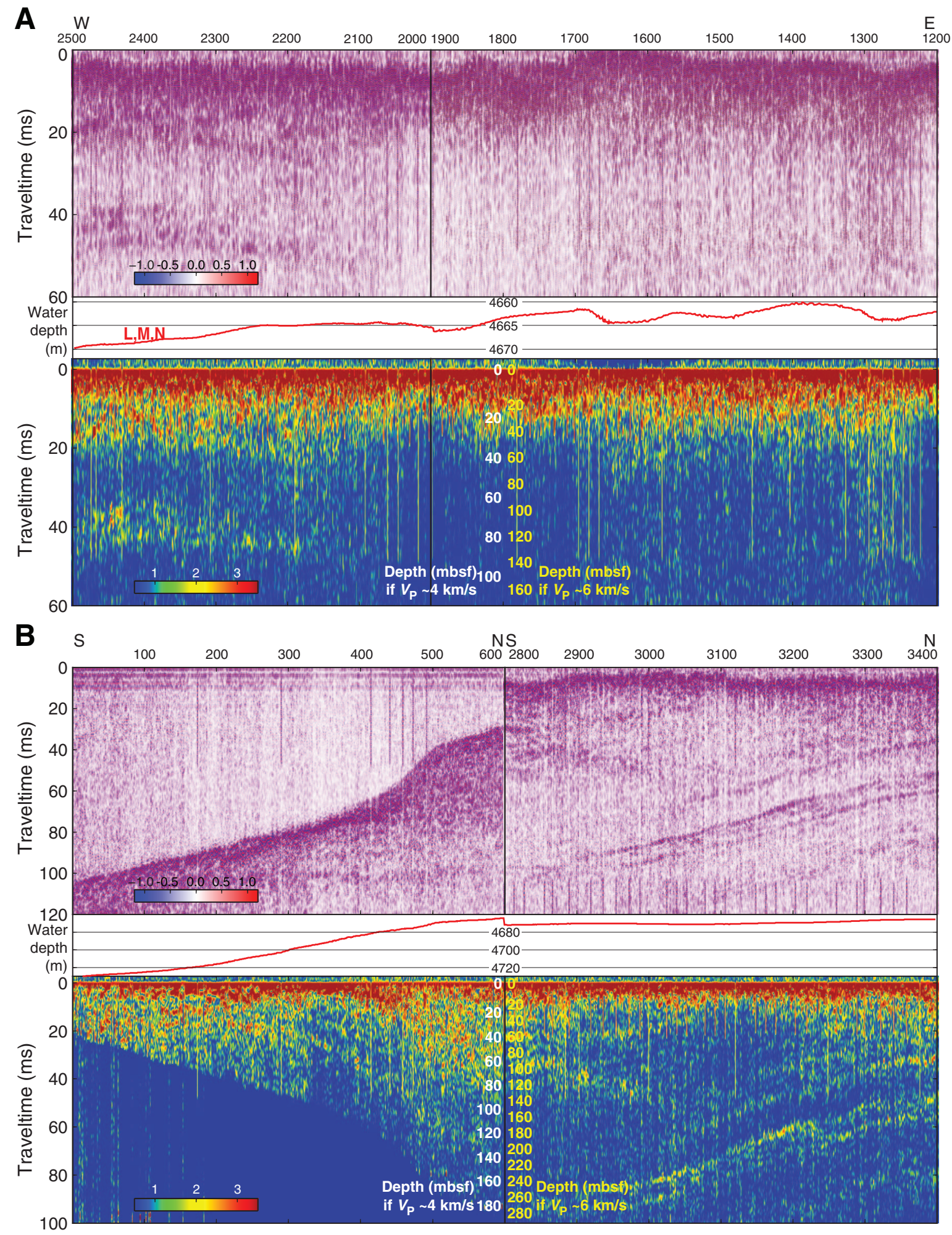
Figure F11. Pinger survey recorded on 25 January and 5 February 2013, Expedition 345. The numbers are the sequential numbers of the traces. The data recorded along the green and cyan sections of the 25 January survey are shown in Figure F12. The data recorded along the red and purple sections of the 5 February survey are shown in Figure F13. The eastern side of the 26 December survey is also shown. Microbathymetry from Ferrini et al. (2013). Contour interval $=5 \mathrm{~m}$.

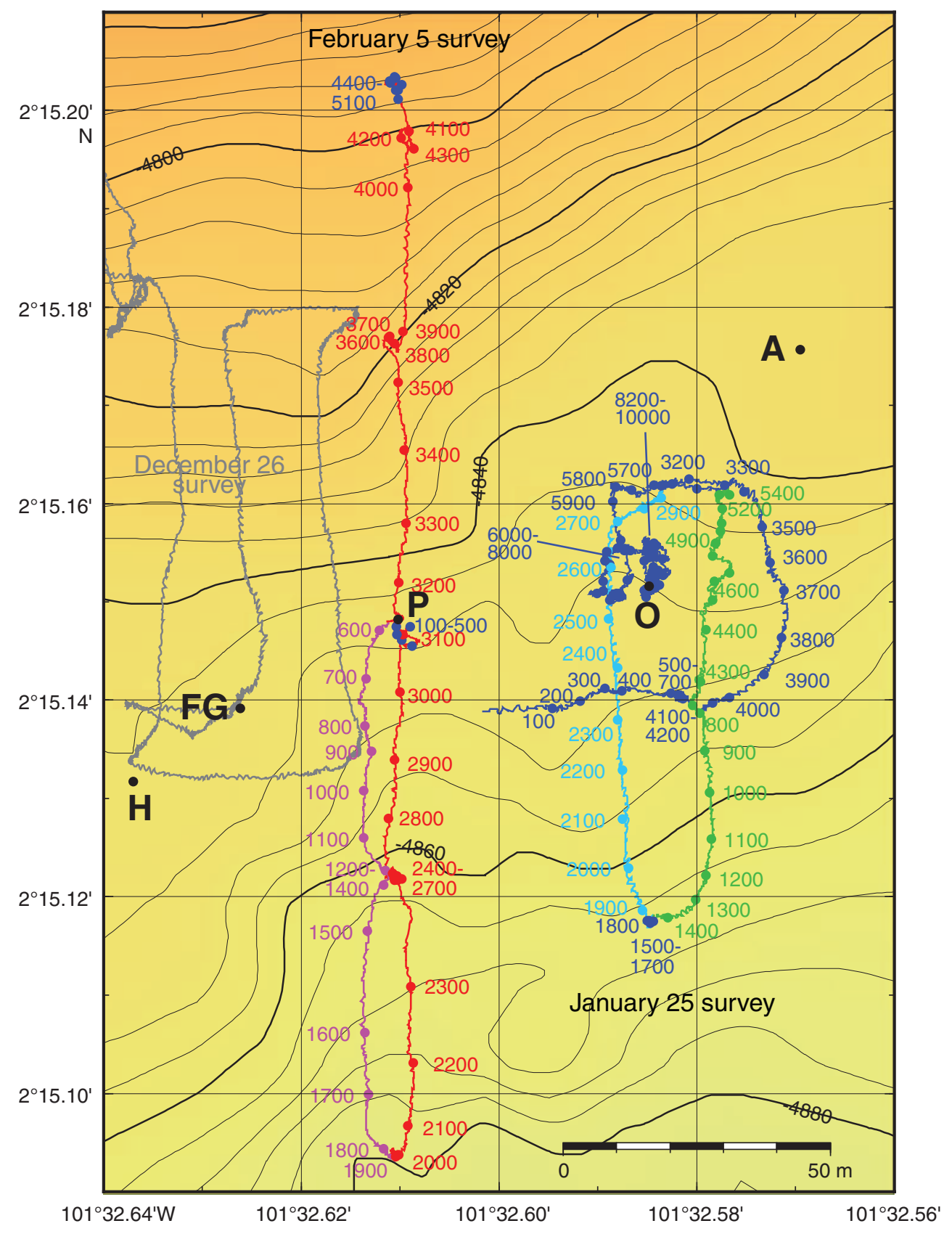


Figure F12. Subbottom profiler data recorded along two north-south sections of the 25 January 2013 survey, Expedition 345. A. Central and eastern side (green in Fig. F11, combining two segments). B. Western side (cyan in Fig. F11). See Figure F5 for details. The approximate location of Hole U1415O is shown on the bathymetry profile.
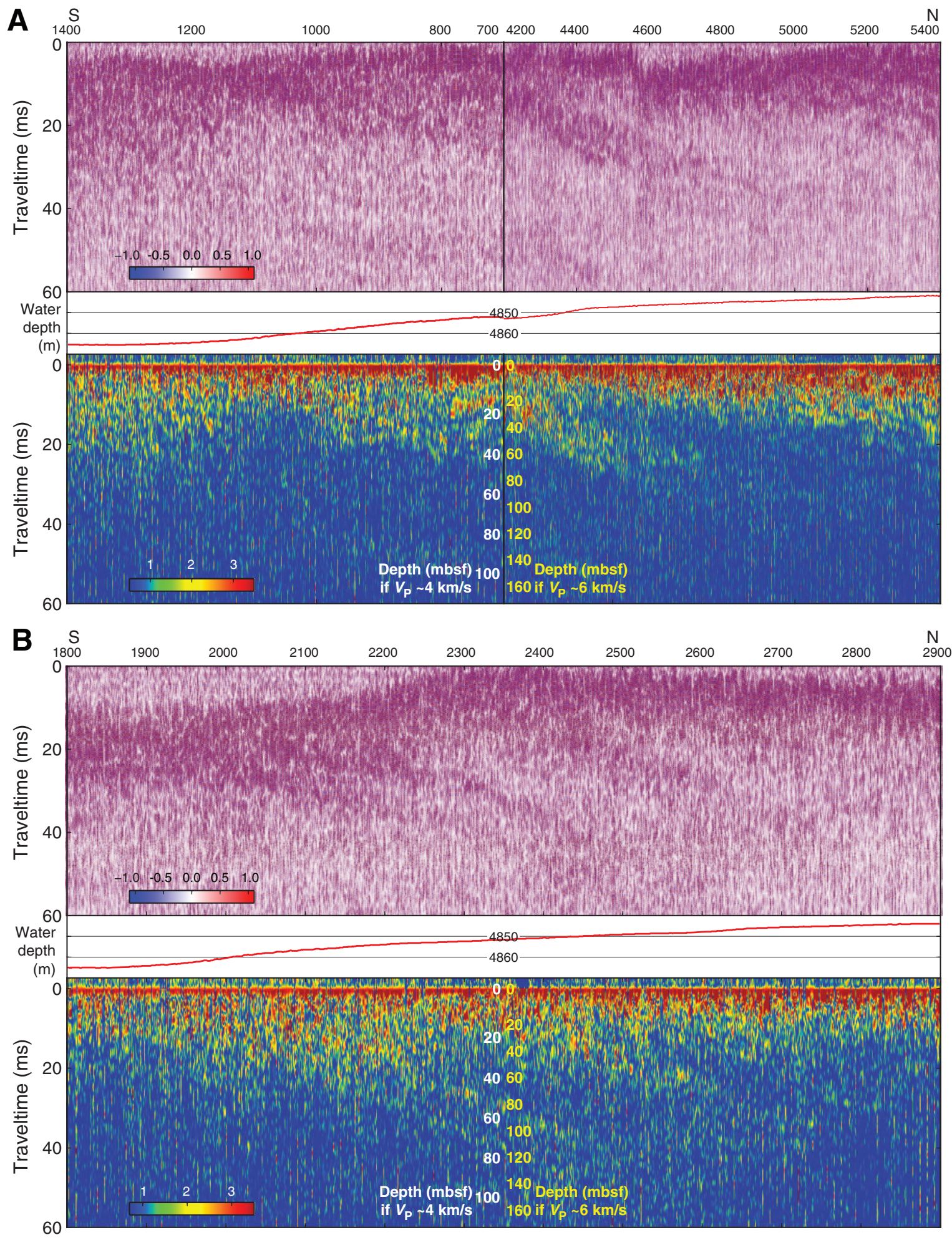
Figure F13. Subbottom profiler data recorded along the two north-south branches of the 5 February 2013 survey, Expedition 345. A. Eastern branch (red in Fig. F11). B. Western branch (purple in Fig. F11). See Figure F5 for details. The approximate location of Hole U1415P is shown on the bathymetry profile.
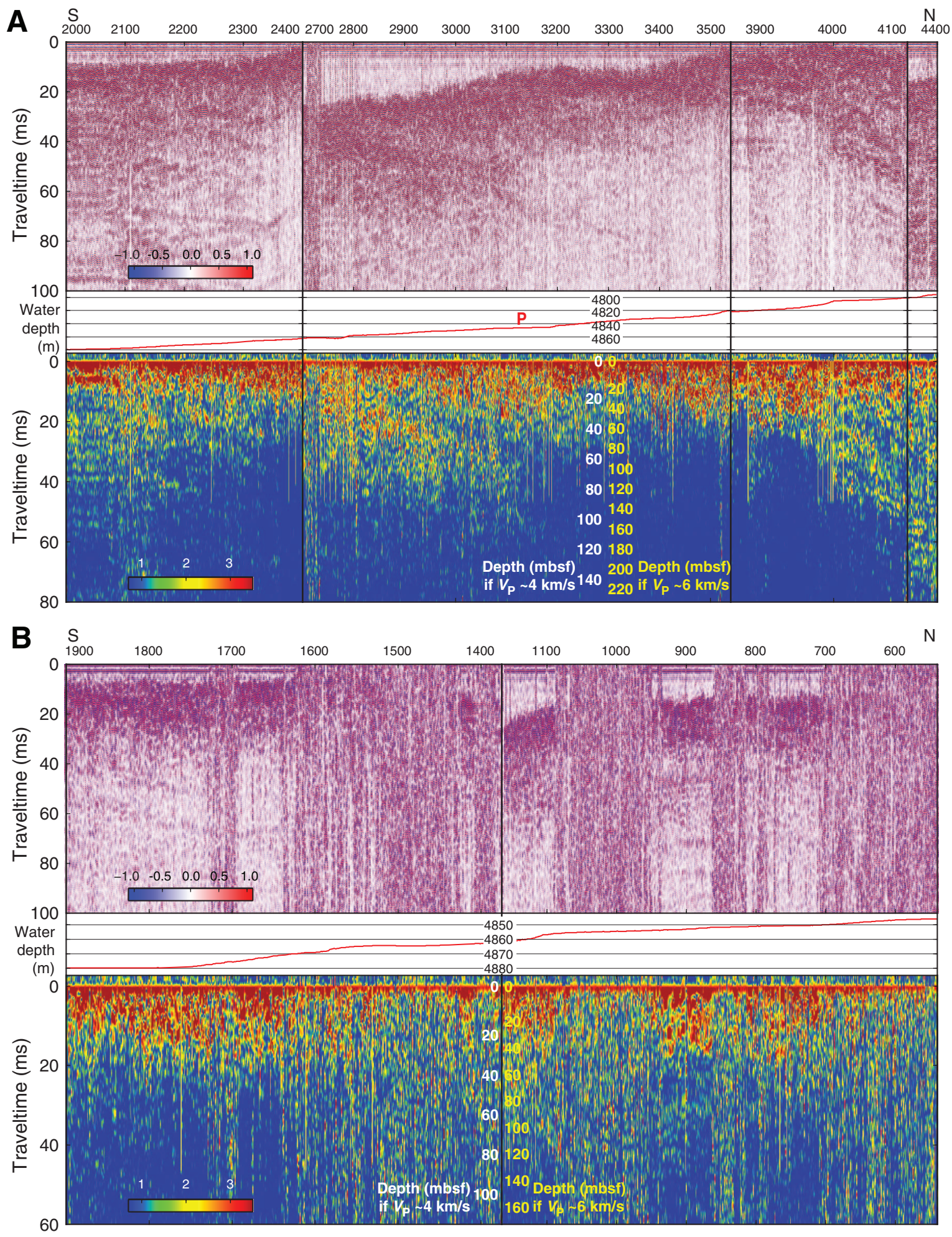
Table T1. Survey operations summary, Expedition 345.

\begin{tabular}{|c|c|c|c|c|c|c|c|c|c|c|}
\hline \multirow{2}{*}{$\begin{array}{l}\text { Survey } \\
\text { number }\end{array}$} & \multirow[b]{2}{*}{ Date } & \multicolumn{3}{|c|}{ Time (h) } & \multirow[b]{2}{*}{ Purpose } & \multirow[b]{2}{*}{ Description } & \multirow{2}{*}{$\begin{array}{l}\text { On-bottom } \\
\text { observations }\end{array}$} & \multirow{2}{*}{$\begin{array}{l}\text { Subbottom } \\
\text { profiler }\end{array}$} & \multirow[b]{2}{*}{ Comments } & \multirow{2}{*}{$\begin{array}{l}\text { Archived video } \\
\text { file name }\end{array}$} \\
\hline & & Start & Stop & Total $^{*}$ & & & & & & \\
\hline 1 & 22 Dec 2012 & 1853 & 2131 & 2.50 & $\begin{array}{l}\text { Locate Hole U1415A, confirm } \\
\text { location of bench, deploy } \\
\text { beacon }\end{array}$ & $\begin{array}{l}\text { S-N survey to Hole U1415A, } \\
\text { survey } 100 \mathrm{~m} \mathrm{~W} \text { of hole }\end{array}$ & $x$ & & & EXP 345 VIT 01 \\
\hline 2 & 23 Dec 2012 & 0206 & 0822 & 6.25 & $\begin{array}{l}\text { Subbottom profiler survey of } \\
\text { bench }\end{array}$ & Parallel E-W transect lines planned & $x$ & $x$ & & EXP 345 VIT 02 \\
\hline 3 & 24 Dec 2012 & 1856 & 2057 & 2.00 & $\begin{array}{l}\text { Continue subbottom profiler } \\
\text { survey of bench, locate Holes } \\
\text { U1415D and U1415E }\end{array}$ & $\begin{array}{l}\text { Move along W-E transect; once } \\
\text { pinger failed, selected site for } \\
\text { jet-in }\end{array}$ & $x$ & & $\begin{array}{l}\text { Pinger failed at beginning of } \\
\text { survey; video starts at } 2007 \mathrm{~h}\end{array}$ & EXP 345 VIT 03 \\
\hline 4 & 26 Dec 2012 & 1603 & 1908 & 3.00 & Locate Hole U1415F & $\begin{array}{l}\text { Move from Holes U1415D and } \\
\text { U1415E to U1415F and U1415G; } \\
\text { box survey around Holes U1415F } \\
\text { and U1415G }\end{array}$ & $x$ & $x$ & & EXP 345 VIT 04 \\
\hline 5 & 27 Dec 2012 & 0739 & 0758 & 0.25 & Locate Hole U1415H & $\begin{array}{l}\text { Move from Hole U1415G to Hole } \\
\text { U1415H }\end{array}$ & $x$ & & & EXP 345 VIT 05 \\
\hline 6 & 28 Dec 2012 & 0705 & 0900 & 2.00 & Locate Hole U1415I & $\begin{array}{l}\text { Move from Hole U1415H to Hole } \\
\text { U1415I; box survey around Hole } \\
\text { U1415I }\end{array}$ & $x$ & & & EXP 345 VIT 06 \\
\hline 7 & 9 Jan 2013 & 1409 & 2025 & 6.25 & $\begin{array}{l}\text { Explore two potential future drill } \\
\text { site locations }\end{array}$ & $\begin{array}{l}\text { First site is flat-lying shoulder } \sim 160 \\
\mathrm{~m} \text { north of bench; second site is } \\
\text { outcrop on the bench sampled } \\
\text { during JC21 site survey cruise }\end{array}$ & $x$ & $x$ & $\begin{array}{l}\text { Pinger failed at } 1602 \mathrm{~h} \text {, part way } \\
\text { through survey }\end{array}$ & EXP 345 VIT 13 \\
\hline 8 & $16 \operatorname{Jan} 2013$ & 1744 & 1930 & 2.25 & Locate Hole U1415K & $\begin{array}{l}\text { Survey } 60 \mathrm{~m} \text { wide region; box } \\
\text { survey around Hole U1415K }\end{array}$ & $x$ & & $\begin{array}{l}\text { Ship moved to start of survey area } \\
\text { during pipe trip; started in } \\
\text { sedimented area found on } 9 \text { Jan } \\
2013 \text { survey; pinger stopped } \\
\text { working before survey started }\end{array}$ & EXP 345 VIT 17 \\
\hline 9 & $\begin{array}{l}\text { 18-19 Jan } \\
2013\end{array}$ & 2315 & 1230 & 1.00 & Examine seafloor at Hole U1415K & $\begin{array}{l}\text { Survey to find hole adjacent to } \\
\text { tipped free-fall funnel for re- } \\
\text { entry }\end{array}$ & $x$ & & & EXP 345 VIT 18 \\
\hline 10 & $20 \operatorname{Jan} 2013$ & 0423 & 0730 & 3.00 & Locate Holes U1415L and U1415M & $\begin{array}{l}\text { Move from Hole U1415K to Holes } \\
\text { U1415L and U1415M }\end{array}$ & $x$ & & $\begin{array}{l}\text { Dropped beacon; pinger batteries } \\
\text { died before start of survey }\end{array}$ & EXP 345 VIT 22 \\
\hline 11 & $23 \operatorname{Jan} 2013$ & 0005 & 0021 & 0.25 & Locate Hole U1415N & $\begin{array}{l}\text { Move from Hole U1415M to Hole } \\
\text { U1415N }\end{array}$ & $x$ & & $\begin{array}{l}\text { Moved } 15 \mathrm{~m} \text { west for single-bit } \\
\text { hole after reentry try for Hole } \\
\text { U1415M failed }\end{array}$ & EXP 345 VIT 23 \\
\hline 12 & $25 \mathrm{Jan} 2013$ & 1252 & 1536 & 2.75 & Locate Hole U1415O & $\begin{array}{l}\text { Move from Holes U1415M and } \\
\text { U1415N to Hole U1415O; } 40 \mathrm{~m} \\
\mathrm{~N}-\mathrm{S} \text { transect for subbottom } \\
\text { profiler, box survey around Hole } \\
\text { U1415O }\end{array}$ & $x$ & $x$ & $\begin{array}{l}\text { Ship moved from Hole U1415N to } \\
\text { Holes U1415F and U1415G } \\
\text { while pipe was being tripped to } \\
\text { bring close to area of interest for } \\
\text { Hole U1415O }\end{array}$ & EXP 345 VIT 24 \\
\hline 13 & $26 \operatorname{Jan} 2013$ & 0926 & 1036 & 1.00 & Locate Hole U1415P & $\begin{array}{l}\text { Move from Hole U1415O to Hole } \\
\text { U1415P, box survey around Hole } \\
\text { U1415P }\end{array}$ & $x$ & $x$ & Pinger signal weak & EXP 345 VIT 25 \\
\hline 14 & 5 Feb 2013 & 0607 & 0848 & 2.75 & $\begin{array}{l}\text { Characterize structure under Hole } \\
\text { U1415P }\end{array}$ & $\begin{array}{l}\text { Move } 100 \mathrm{~m} \text { north and south of } \\
\text { Hole U1415P }\end{array}$ & & $x$ & Finished survey operations & EXP 345 VIT 25 \\
\hline
\end{tabular}

* $=$ to nearest quarter hour. Time is local ship time (UTC $-7 \mathrm{~h}$ ). Archived video is available from the IODP Data Librarian. 